\title{
Financial Reporting - the Private - Public Partnership Prospective - the Case of Albania
}

\author{
Kledian Kodra, Ms.C. \\ Senior Audit Manager at PwC (Albania) \\ kledi.kodra@al.pwc.com \\ Doc.Ines Dika \\ Lector, Agricultural University of Tirana \\ ines.dika@virgilio.it
}

\section{Doi:10.5901/mjss.2015.v6n2s2p117}

\begin{abstract}
In the wake of the recent trend in governments stepping back from performing administrative duties aiming at improving service quality of citizens, Albania has witnessed a rapid growth in the Private - Public Partnerships (PPP). The ever growing confrontation of the government with the challenge to improve infrastructure and public facility planning grows proportionally with the increase in demand from the population as well as the need for enhancing existing infrastructure and public facilities, which suffer from delayed maintenance interventions. One of the distinguishing features of the latest developments in Albania is the boost in the number of PPP arrangements completed and in progress, aimed at meeting different infrastructure objectives, efficient mining exploitation, construction of Hydroelectric power plants and various public facility centers offering an array of public services etc. The PPP arrangements take a number of forms depending on the degree of involvement in the private sector and according to the methods used for their implementation.In this paper we are going to focus only on the accounting and financial reporting aspect of these issues, from the prospective of the public sector entity, i.e. the offer, by giving limited consideration to the operators of these agreements due to the fact that the accounting treatment and the respective financial reporting for Service Concession Agreements for private operators are covered by IFRIC 12 of the Interpretations committee for the International Financial Reporting Standards on "Service Concession Arrangements".
\end{abstract}

Keywords: Financial Reporting, Public Partnership Prospective

\section{Introduction}

Due to recent trends in which governments continuously step back from performing administrative duties and with the purpose of improving the quality of the services offered to the citizens, the Private - Public Partnerships (PPP) is rapidly growing in Albania, by raising the efficiency of the public investments. Governments are facing now more than ever the challenge to create the infrastructure and the public facilities, which should comply with the increase in demand from the population. They are also facing the need to enhance existing infrastructure and public facilities, which are deteriorating due to the delayed maintenance.

One of the distinguishing features of the latest developments in Albania is the boost in the number of PPP arrangements agreed upon and the ones that are in progress, aimed at meeting different infrastructure objectives, efficient mining exploitation, construction of Hydroelectric power plants and various public facility canters offering an array of public services etc. The PPP arrangements take a number of forms depending on the degree of involvement in the private sector and according to the methods used for their implementation.

A specific form of this partnership is the Concession Agreement (CA) which differs from other forms of PPP agreements because the risks and benefits that associate with the construction, ownership and use of the asset (property) subject to the agreement, along with the control over it, are largely separated between the public sector entity and the private sector involved in the agreement. The separation of these aspects of asset/property and the complexity of the transactions has often made uncertain the financial reporting by public entities as well as the private ones. Examples of these agreements are the use and maintenance of a highway from a private company against a fee, production and distribution of national passports, the production of excise stamps, construction operation and maintenance of the large parking lots, construction and operation of hydropower, etc. All of the above examples that are already present in the Albanian economy have on their basis the acceptance of the responsibilities from the companies that make the 
investment even after the completion of the investment.

In many cases, if not most of them, the execution of these agreements with the private sector requires their cooperation with the banks to provide for the necessary financial means (such as the case of HPP), where the guarantee of obtaining credit can be given by the public sector or from different agencies or donors. Under such circumstances, financial reporting takes the meaning of reliable information given to all parties involved.

\section{Backgrounds and Issues Related to Financial Reporting Agreements of the PPP}

Although in Albania there is no clear guidance on the accounting and reporting by public sector entities for the property subject to concession agreements, of assistance in this regard may be the framework of the International Accounting Standards Board (IASB Framework) and the standard lease agreements and suggestions to the International Public Sector Accounting Standards Board (IPSAS). The lack of specific regulations on this issue, has brought divergence in the way of reporting the property/asset or service. It may unfortunately happen that the property is not reported as such from neither the public nor the private sector.

In this paper we are going to focus only on the accounting and financial reporting aspect of these issues, from the prospective of the public sector entity, i.e. the offeror or provider, by giving limited consideration to the operators of these agreements and this is due to the fact that the accounting treatment and the respective financial reporting requirements for Service Concession Agreements from private operators are covered by IFRIC 12 of the Interpretations Committee for the International Accounting Standards Board on "Service Concession Arrangements".

If the financial reporting on assets was to be based only on legal ownership, we would not be able to achieve financial reporting that faithfully reflects the assets based on the principle that "economic substance prevails over legal form". This is why it becomes necessary to analyze the relationship between the parties as well as the asset or activity subject to the agreement.

According to the International Public Sector Accounting Standards (IPSAS) the assets are defined as "resources controlled by one entity, which arise from activities in the past, from which are expected possible future or potential income of economic benefits. The notion of control over resources is clearly presented in the definition. Given the definition, that the provider has to report the property subject to the concession agreement as an asset, it should have a control over the property, but also receive future economic benefits or service potential.

The control over the use of the property is the key principle that is reiterated in the conclusions given in the IFRIC 12. According to this principle the private operator should not report as an asset of his own an asset subject to an agreement that is regulated by this interpretation. According to this interpretation, the private operator does not recognize the property as an asset but recognizes an intangible or a financial asset that reflects the right that has been granted to him by the offeror to use the property or receive contractual cash flows. According to the IPSAS Board, the nature of the criteria included in the scope of application of the IFRIC 12 generally is appropriate to determine whether the provider has complete control (substantial) on the property under such agreements for financial reporting purposes. These criteria taken into consideration together indicate that a) the provider will have a continuous right to ask for the property to be operated in such a way as to fulfill public service throughout the whole agreement and beyond, and b) the operator's practical ability to sell or pledge the property is limited.

Regardless of the operators' control over the provision of certain aspects of services that have resulted from wealth, the general use of this property remains limited to the providers' target set in the agreement. Furthermore, the concession provider controls the key operational aspects of the property, such as, for example, the fees to be applied to its use.

If criteria similar to those in IFRIC 12 are met, it is widely accepted that the operator operates the property on behalf of the provider, and the latter has ultimate control over the property.

Based on the instructions of IPSAS 23 and IPSAS 6, it can be argued that if the grantor's control over the assets underlying these agreements is similar to regulatory control, only one control of this kind is not sufficient to meet the concept of control included in the definition of an asset for financial reporting purposes providers.

For example, the government may transfer an area of land to a public university specifying that the land will be used only to construct the campus. Under IPSAS 23, despite this definition, the public university (in this example "user") controls the land and will present it as an asset in its financial statements. The university needs to recognize also a liability, if the determination shall be considered as a condition, which means that if the land is not used for the purpose for which it is given, then it will be returned to the rightful owner. Results of financial reporting in this example may seem in conflict with the guidelines discussed above concerning the control over property of this agreement, where the party that imposes restrictions on the use of assets (provider) and not the user of the asset (operator) is considered that 
controls the property for financial reporting purposes. The crucial difference between this example of land transfer to the university and the service concession arrangement is that the grantor holds control of the remaining interest in the underlying assets of the agreement until its end. In typical arrangements such as those discussed above, the asset at the end of the agreement is not returned to the transferor. Even where predestination is provided, upon fulfillment of this condition the asset remains with the operator, so in the case of the University at the time that the land will be used to build the campus, the asset (land) remains, to be reported in the statements of the University.

\section{Future Economic Expected Benefits or Services Potential}

Even though the provider in an agreement can control the use of property, in order to meet the definition of an asset by IPSAS 1, as mentioned above, the property should bring a stream of expected future economic benefits or service potential to the provider. IFRIC 12 concludes that the use of the property, subject to these agreements regulated by this interpretation, is not controlled by the operator (it does not meet the definition of an asset for the operator). IFRIC 12 covers only for private operator accounting and does not address the flow of benefits from the property to the provider.

The aspect of the potential service as future benefits that can come from an asset is the main difference between the definition of an asset under IPSAS 1 and that according to the IASB framework, which focuses only on future economic benefits. "The potential of services" further explained in paragraph 11 of IPSAS 1 as follows:

Assets provide means for the entities to achieve their goals. The assets used to supply goods and services in accordance with the objectives of an economic entity, but don't generate direct net cash flows are often described as containing "service potential". For example, a road where no fees apply for transfer is considered as an asset for the government because it provides services in order to achieve government objectives in relation to transport, although it does not generate future economic benefits for the government. In general, governments enter into such agreements concession to fulfill the objectives of the service through the construction, renovation, or improvement of the property subject to the agreement. In this way, the property subject of the contract is intended to provide benefits to the provider, related to the potential of their services, even if the property will not provide any economic benefit in the future. Even though the main reason for the provider to enter into such an agreement is the economic benefit, for example to receive in advance a cash influx in exchange for the rights to operate a road, the property subject to the agreement will continue to be used to accomplish government objectives - it would be operated only by a private operator, so it will offer service potential benefits grantor.

For example, let's take into consideration a national road operated free of charge that is reported as an asset by the provider, based on its potential for services. Let us assume that this road becomes the object of a concession agreement according to which the operator is entitled to decide charges for the road users, in return he takes the responsibility to make repairs and renovations, as well as make use of the road according to the specifications of the provider. If it is proved that the provider has control over the road under the conditions specified in the contract, then he will have the same benefits he had before the execution of such agreement, despite the fact that the provider has spent a good part of the risks and benefits to the operator. Therefore, it seems that the road must continue to appear as an asset of the provider because its basis that requires its reporting as an asset has not change, so it is an asset of the provider based on potential service.

Furthermore, it can be argued that in the cases the provider controls the property, the operator operates deeply the asset on behalf of providers, then he is a supplier of services to the concession provider. The economic risks and benefits assumed by the operator through the agreement may be similar to those of a seller to a service contract. They differ from the risks and benefits associated with ownership of these assets.

However, the economic risks and benefits may be associated with an active private operator reported as a result of "access" in this property. For example, the operator shall report an asset as intangible under IFRIC 12 because future income depends on the public use of the service and is not guaranteed.

Current proposals by the IPSAS Board, which can be adopted as practical even in our country, suggest that the concession provider must report the asset in its financial statements, if it is considered that controls property for financial reporting purposes. The proposed criteria for determining control by the providers are as follows:

The provider controls what services should the operator provide making use of the property subject to the agreement, to whom should these services be provided, prices associated with these services, etc.

The provider controls, through ownership, or through any other cause - a residual interest in the asset until the end of the agreement.

According to the Board, the providers' control over the asset subject to the agreement, proves that the provider remains responsible for providing direct or indirect public services, which relate to an asset. The fact that the provider is 
keeping the risks and benefits shows that the latter expects to receive from the property potential for services in the future.

\section{Other Accounting Aspects and the Financial Reporting}

For agreements that meet the proposed control criteria it is a good practice to use the requirements of IPSAS 7 , regarding the timing of recognition of the asset (during construction or only when the asset becomes usable) and the liability associated with this asset, which in fact reflects the obligation of the provider to compensate the operator regarding the property (asset). Recognition criteria will be met during construction, if the value of the construction in process can be measured accordingly. This applies when the provider bears the risk of construction or when both parties can waive the agreement when they want to do such a thing without being paralyzed. If none of these scenarios is fulfilled, then the recognition criteria are not likely be completed until construction is finished.

Specific requirements have also been set regarding the agreements where the elements of construction and service may (or not) be separated within the scheduled payments by the providers.

If, however, for some concession agreement none of the proposed control criteria is met, as discussed above, the provider does not have to recognize as an asset subject to this agreement. Consequently, any payment to be made to this CA is for its service and not for the asset/property, and therefore should be spent according to the economic benefits of the service. Also, if the property exists and is held as an asset by the provider, according to IPSAS 17, it should be derecognized.

For concession agreements in which the provider only controls the use of the property during the agreement (for example in the form CA building-ownership-operation), the tenant must follow the instructions in IPSAS 13 if the agreement meets the requirements of a lease contract. If, however, the provider controls only the use of the property during the agreement and the agreement does not meet the terms of a finance lease, because the provider retains ownership during the period of the agreement, then the provider must report the property as an asset. If, however, the agreement includes a newly built property, the asset and the liability related to it shall be reported and measured as described above regarding the financial reporting provider when control criteria are met. At the end of the agreement the remaining accounting value of the property will be deregistered, reflecting the transfer of property to the operator. If the agreement does not meet the terms of a finance lease and the provider is not the owner of the property, then it will not be recorded as an asset and any payment in connection with this property / asset would be an expense of the period.

For agreements involving assets / properties that are newly constructed, where the provider does not control the use of the asset / property during the agreement, but instead it controls remaining interest in the asset / property at the end of the agreement (for example the BOOT form agreement), the provider reports as an asset the excess of the value arising from the difference between the expected fair value of the property right at the end of the agreement and the amount that the provider will be required to pay to the operator for the restitution of the property. This asset reaches gradually its accounting value of the payments made by the provider to the operator during the whole the agreement.

For arrangements involving existing assets in which the provider does not control the use of property during the time of the agreement, but instead it controls the residual interest at the end of the agreement, the Board proposes to follow the guideline that applies to the lessor by IPSAS 13, if the agreement meets the definition of a lease contract. If the agreement does not meet this definition, the provider derecognizes the asset (property) and recognizes as an asset the obligation of the operator to return the property at the end of the agreement.

\section{Provisions for Revenue Sharing}

In the cases of agreements where the operator is expected to raise revenue from direct fees imposed to third parties or by the users of the public good, usually the provider negotiates to include in the contract a provision for these revenue sharing between him and operator. In this way, if the property use exceeds expectations then the operator will share success with the provider. This provision would serve to protect the provider from political risk and public criticism that could arise due to involvement in an agreement, which may be more profitable for a private operator. For example, as part of a BOOT agreement for the construction of a large parking lot, the provider receives a fixed fee for each ticket sold. The provider uses this fee to finance activities of the community. Another example would be a deal that includes the construction of a toll road, whereby the provider is entitled to receive $40 \%$ of the total income as net flows from the agreement offer to the operator a pre-tax rate of return of $6.5 \%$ on the total funds invested. The part of the provider increases to $80 \%$ of the total revenue collected as cash contract gives to the operator a rate of return of $8 \%$.

Provisions of revenue sharing are often included in the terms of an agreement along with a minimum guarantee for 
the operator. For example, an agreement for the operation of a toll road contains a provision for revenue sharing. This provision requires the provider to benefit about $57 \%$ of the income that exceed those predicted. This provision may be accompanied by other provisions where the provider will pay $80 \%$ of any negative gap between the predicted and current revenue. The provider minimizes the risk of demand by giving to the operator a kind of guarantee for minimum income, which if the project results successful has the potential to be even bigger. Current proposals of the Board emphasize that providers should recognize these revenues (and receivables) as they are earned, along with the substance of the agreement and after any contingency event has been met (such as the excess of the minimum threshold of income).

\section{Consolidation}

When the operator is a government business enterprise, there will always exist some of the control indicators discussed in paragraphs 39 and 40 of IPSAS 6, especially if this kind of enterprise is created to serve as an operator in the concession agreement. This operator, in general, should be consolidated in financial statements of the providers.

In cases the operator is an economic entity, then it is an economic entity for specific purposes and the control indicators described in paragraph 39 of IPSAS 6 would not be valid between the operator and the provider. However, the contractual terms of these agreements may result in the presence of several indicators of control given in paragraph 40 of ISPSAS 6. For example, in an economic entity for specific purposes that is created for a toll road, the following provisions of the contract may be indicators of the control strength of the providers over the operator:

The operator is allowed to take a loan as specified in the contract and the provider must approve in advance any additional debt.

All payment charges for crossing the road are subject of approval by the Minister of Transportation and may differ depending on the requirements of providers.

The provider may request to dismiss every employee who is incompetent, rude etc.

The provisions of the agreement in this example, which may indicate that the provider receives benefits from the activities of the operator are as follows:

It is necessary for the operator to ensure that the highway will be open to traffic at all times and that traffic flow meets predetermined standards that accomplish objectives of the provider regarding transportation.

The operator will make payments to providers if the return of the project exceeds a certain limit.

\section{Conculsions and Recommandations}

A distinctive feature of developments nowadays in Albania is the rising number of PPP agreements completed and those in the process, for the implementation of various investments in infrastructure, for efficient utilization of mining, construction of HPP, centers and various facilities public, various public services etc.

PPP is a new and important means to increase the efficiency of government investment funds with the aim of taking responsibility on both sides.

Currently accounting treatments and adequate financial reporting by private operators for the concession agreements are covered by IFRIC 12 Interpretations Committee of the Board of the International Accounting Standards "Service Concession Arrangements".

Based on the instructions of IPSAS 23 and IPSAS 6, it can be argued that if grantor's control over the property subject to the agreements is similar to regulatory control, only such control is not sufficient to meet the concept of control included in the definition of an asset for financial reporting purposes of the provider.

The aspect of service potentials as future benefits that can come from an asset is the main difference between the definition of an asset under IPSAS 1 and that according to the framework of the IASB, which focuses only on future economic benefits.

Although the main motive of the provider to enter into such an agreement is the economic benefit, for example, to receive an influx of cash in advance in exchange for the rights to operate a road, the property subject of the agreement shall continue to be used to achieve government objectives - it would only be operated by a private operator, so that will offer potential benefits to its service provider.

Current proposals from the IPSAS Board, which can be adopted as practical even in Albania, suggest that the concession provider must report the asset in its financial statements, if it is considered it that controls the property for financial reporting purposes. 


\section{References}

Ministry of Finance, Albania "Albanian Macroeconomic Indicators" (2012)

Ministry of Finance, Albania, "Albanian Macroeconomic Indicators" (2012)

Ministry of Finance, Albania, "Albanian Macroeconomic Indicators" (2013)

OECD - Working Party of Senior Budget Officials "From Lessons to Principles for the use of Public-Private Partnerships"

EU law on public procurement and concessions in relation to public-private partnerships - 2004 Green Paper - how procurement law applies to different forms of public-private partnerships

IPSASB consultation Paper

IFAC website

IASB Framework 